\title{
Participation of yeast-like fungi in respiratory system diseases tuberculosis and neoplasms
}

\author{
MARIA DYNOWSKA, ANNA BIEDUNKIEWICZ and EWA SUCHARZEWSKA
}

\author{
Department of Mrcology, University of Warmis and Mazury in Olsatyr \\ Oczapowskiego 1A, PL-10.957 Olstyn
}

Dynowska M, Biedunkiewicz A., Sucharzewska E. Participation of yeast-like fungi in respinutory system discoses tubercuiosis and nteoplasms. Acta Mycol. $37(1 / 2): 117-122,2002$.

The following paper contains the research resuits (1997.1999), concerning the presence of yeast-like fungi in the human respiratory system (sputum, broochoseopy material) of 1315 patients of the Specialistic Public Hospital of Lung Diseases and Oncology in Olsztyn with the neoplasm development process and suspicion of tuberculcsis. In the sudied group the majority of paticnts with acoplasans (452 pcopic: 311 female and 141 male) were infected with fungi. They were isolated frem 280 women (919\%) and 130 men (92\%). Among 78 pecple suspicion of tuberculosis and treated with series of antibiotics only in two cases mycobacterium was obtained. All the 76 patients the presence of mycobackrium was aot found, although. the clinical symptomps and radiological researches indicated tuberculosis. In total 9 species fungi were isolated: Candida, Saccharomycopsis and Trichosporon. The Candida alhicans dominated. The results obtaincd confitm negative influence of the modern antibiotics and neoplastic discases therapy, which suecession is the drastic decrease in cellular resistance ad activity of patbogenic fungi often imitating symptoms other diseases (c.g. tuberculosis).

Key words: yeast-like fungi, respiratory system, neoplasms, tuberculosis

\section{INTRODUCTION}

Among many diseases related to the development of civilization, not dismissing the state of the art therapy, mycoses of organs dominating in ontocenoses of those organs that have direct contact with the external environment pose an increasingly important problem. The respiratory system, which is penetrated by fungi per os or as a result of inhalation, is one of such systems. A continuous increase in the numbers of respiratory system mycoses (Dy nows ka 1995) results not only from the abundance and biological diversification of pathogens but also by the expanding spectrum of their pathogenicity (Dy nows ka 1993) as well as a decrease in human body resistance to fungal infections. This applies to people in different age groups. Continuous underestimation of fungi as a potential source of numerous very serious diseases is a 
concern, the more so as the range of factors predestining their appearance cxpands continuously.

Besides the iatrogenic factors (the major ones are hypertension, unsuitable and uncontrolled antibiotic therapy), a very important role is played by pathological factors: tuburculosis and neoplastic diseases (Batura-Gabryel et al. 1994; Verthalitis and Meunier 1995; Krajewska-Kułak et al. 1999).

It was decided then to check what is the participation of increasingly expansive yeast-like fungi in those diseases.

\section{MATERIAL AND METHODS}

The research material consisted of yeast-like fungi isolated from the respiratory system (sputum, bronchoscopy material) of 1783 patients of the Specjalist Public Hospital of Lung Diseases and Oncology in Olsztyn during the years 1997-1999,

The research was conducted at the Bacteriology Laboratory according to the generally accepted methody and guidelines for bacteriological and mycological diagnostics (Richardson and Warnock 1995; Vertalitis and Meunier 1995).

Cultures of fungi were grown of solid and liquid Sabouraud medium at $37^{\circ} \mathrm{C}$ for 48-72 hours. He fungi were identified taking into consideration their macroscopic features on Sabouraud agar, microscopic ones on Nickerson agar and bjochemical ones obtained from bio-Merieux tests (Kurnatowska 1995). Works by Kre. ger-van Rij (1984), Barnet et al. (1990) Kurnatowska (1995) and were used for identification purposes.

In analysis of the results, the qualitative composition of mycoflora of patients with neoplasms and tuberculosis was considered, including also the patients with symptoms of tuberculosis but BK $(-)$, and the sex of the patients.

\section{RESULTS}

In total 1315 patients were analyzed, i.e. those cases in which the fungal growth was abundant: 892 cases $-50 \%$, and very adundant: 423 cases $-23.7 \%$ (Table 1 ). In the studied group, the majority of patients with the neoplasm devclopment process in progress ( 452 people, including 311 female and 141 male) were also infected with fungi. The fungi were isolated from 280 women $-90 \%$ of cases, and 130 of men $-92 \%$ of cases (Figure 1). Instead among 78 people suspicion of tuberculosis only in two cases mycobacterium brought up. All the 76 patients presence of mycobacterium was not found although the clinical symptoms and radiological results indicated tuberculosis. Those results represented $18 \%$ of the cases with the most abundant fungal growth.

\section{Table ]}

Proportional participation of yeast-like fungi in analysing of material with regard to intenseness of growth

\begin{tabular}{|c|c|c|c|}
\hline Number of paticnts & abundant & very abundan & weak and muderate \\
\hline 1783 & $892(50.0 \%)$ & $42.3(23.7 \%)$ & $468(26.3 \%)$ \\
\hline $100 \%$ & \multicolumn{2}{|c|}{$1315(73.7 \%)$} & $468(26.3 \%)$ \\
\hline
\end{tabular}




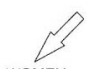

WOMEN

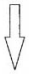

311

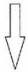

$280(90 \%)$
452

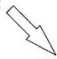

MEN

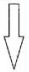

141

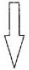

$130(92 \%)$

Fig. 1. Number of analysing patients with the neoplasms were infected with fungi

Neopalstic and tuberculosis changes were accompanied by growth of Candida, Trichosporon and Saccharomycopsis types fungi.

In total, 9 species of fungi, which were present individually, in twos and in case of one patient three together (Table 2) were isolated.

The most frequently isolated fungi were $C$. albicans and $C$. guilliermondii, less frequently Trichosporon beigelï and Saccharomycopsis capsularis (Fig. 2). C. albicans was the fungus that most frequently accompanied other species (Table 2).

\section{Table 2}

Yeast-like fungi isolated in the respiratory system of patients with neoplasms and suspicion of tuberculosis

\begin{tabular}{|c|c|c|c|c|c|}
\hline \multirow[b]{2}{*}{ L.p. } & \multirow{2}{*}{ Species of fungi } & \multicolumn{4}{|c|}{ Occurence } \\
\hline & & individually & in two & & three \\
\hline 1. & Candide albicans Berkhout & $\mathrm{x}$ & $x+77$ & $x$ & \\
\hline 2. & Candida guilliermondii Langeron et Guerra & $\mathrm{X}$ & $x$ & & \\
\hline 3. & Cendida parapsilosis Langeron et Tulice & $x$ & $\mathrm{x}$ & & \\
\hline 4. & Candida tropicalis Berkhout & $\mathrm{X}$ & $\mathrm{x} \quad$ & & \\
\hline 5. & Saccharomycopsis capsularis Schionning & $\mathrm{X}$ & $\mathrm{X}$ & & \\
\hline 6. & Saccharomycopsī sp. & $\mathrm{X}$ & $\mathrm{x}$ & $\mathrm{X}$ & \\
\hline 7. & Trichorporon betgelii Viltemin & $\mathrm{x}$ & $\mathrm{x}$ & & \\
\hline 8. & Trichasporon capitatum Diddens et Lodder & $\mathrm{x}$ & $\mathrm{x}$ & & \\
\hline 9. & Trichosporon sp. & $\mathrm{x}$ & $\mathrm{x}$ & $\mathrm{x}$ & \\
\hline
\end{tabular}

Two fungi were not traced to a specific species but it should be pointed out that the Saccharomycopsis sp. had the largest number of $S$. capsularis features while the Trichosporon sp. was most similar to T, beigelii. 


\section{DISCUSSION}

In view of the increasing frequency of infections with opportunistic microorganisms, among which the yeast-like fungi are included, particular attention should be focused on comprehensive clinical examinations and diagnostics oriented at effective control of fungal infections threatening to life. This applies in particular to the patients belonging to the increased risk group in case of whom fungal infections are the major causc of morbidity and mortality among the hospital treated patients (Senet and Robert 1995; Verthalitis and Mcunier 1995). The pereentage share fungal infections in the total number of hospital infections increased from $6 \%$ in 1980 to $10.4 \%$ in 1990 while the number of fungemia increased from $5.4 \%$ to $9.9 \%$ (K rajewska-Kutak et al. 1999). The above data corresponds to the progress that made in antibiotic therapy in case of tuberculosis or even suspicion of tuberculosis and therapy of neoplastic diseases. It frequently happens that presence of fungi is confirmed in almost every biological material collected from the disease lesion. However, fungi are much more frequently isolated in case of patients with neoplasms than those with tuberculosis. In both cases we deal with a drastic decreasc in cellular resistance, which is furthered by aggressive therapy: series of antibiotics with a wide spectrum of influence, cytostatic medicines, corticosteroids and irradiation. All of that facilitates direct or indirect fungal infestation of the system.

Antibiotics lead, first of all, to dysbacteriosis of the alimentary tract and change the permeability of the epithelium and as a result facilitate fungal penetration of the lymphatic and cireulatory systems. Cytostalic and corticosteroid medicines have immunosuppressive effects, they inhibit development of antibodies, distort the activity of macrophages, disable regeneration of mucous membrane in intestines and lead to scvere and long-term neutropenia which favors development of mycoses (Verthalit is and Meunier 1995). The above mentioned represent just a small sample of therapeutic activities that cause a risk of mycosis development.

A large number of mycoses was described in case of patients with neoplastic diseases, tuberculosis and other diseases of lungs (Zagóreck a 1971; Warnock and Richardson 1991; Batura-Gabryel et al. 1994; Senet and Robert 1995; Batura-Gabryel 1999) however, the most frequent ones are candidoses, in case of which $C$ albicans and $C$. tropicalis, and in case of patients on extra-intestinal feeding also $C$. parapsilosis are the major etiological factors (Verthalitis and Meunier 1995). The results obtained confirm the domination of the same Candida type fungi, but at the same time draw attention to a very important phenomenon. This phenomenon is an increasingiy frequent appearance and growth of fungi that so faar have rarely been recorded in the respiratory system. Those fungi include, first of all, Trichosporon type fungi, which used to be isolated most frequently from the skin as a permanent component of its microflora. At the time of collapse of resistance those fungi become aggressive and start colonizing all systems, with a preference for the respiratory system. This is important as during the recent years a significant blurring of differences between ecological groups of pathogenic fungi and an increase in the pathogenicity of species rarely mentioned as significant etiological factors has been observed (Dynows ka 1993). Currently, it is believed, that all fungi which may develop in the human body temperature and are able to survive in the environment of a de- 
creased oxidation-reduction potential (conditions in the damaged and sick tissue, should be considered as potential pathogens (Richardson and Warnock 1995). Presence of fungi in the respiratory system does not have to indicate a situation of direct threat, however, isolation of fungi from bronchoscopic material (ca. $70 \%$ of the entire studied material) may not be dismissed and it suggests development of a discase process. That is why it is a very important task for the diagnosticians and doctors taking care of the patients with neoplastic discases or tuberculosis to differentiate between colonization by fungi and invasive infestation with them (Verthalitis and Meunier 1995). It should be added that presence of symptoms of tuberculosis, without confirmation of mycobacterium presence in a culture, does not have to indicate the developing disease, however, in spite of that, all patients suspected of tuberculosis are treated with series of antibiotics destructive for the body. As yeast-like fungi often imitate the symptoms of tuberculosis, it is possible that many severe life threatening diseases of the respiraatory systems are unidentified mycoses. This is indicated by examinations of post mortem material (Verthalitis and Meunier 1995).

That is why it is very important to conduct careful mycological examinations of people from the physiological risk group (Warnock and Richardson 1991; Senet and Robert 1995), in particular those who return for hospital treatment on many occasions. At the same time, compulsory mycosis prevention should be applied before initiating and during antibiotic therapy or chemical therapy. It is very important as in patiens with lung cancer dependence was found within increase in fungal infestation and the progress or remission of the disease and the number of fatalitics (Batura-Gabryel et al. 1994). Much of the data indicates that long-term untreated mycosis may lead to neoplastic changes as the substances produced by fungi (mycotioxins and enzymes) have a cytotoxic and carcinogenic effect (Bat u ra-Gabryel et al. 1994).

All the time to little attention is taken of the problem of mycoses, which in the majority of cases are secondary, i.e. dependent on therapist and awareness of the patient.

\section{REFERENCES}

Barnet J. A., Payne R. W., Yarrow D. 1990. Ycasts: Charketeristic and identification. Cambridge Univ. Press.

Batura-Gabryel H., Adamski Z., Wieczorek U. 1994. Ocena wpływu zakazenia grzybiczego układu oddechowego na stan ogólny chorych z rakiem pluca. Mikol. Lek. 1 (2): 101-105.

Batu ra -Ga bryel H. 1999 . Inwazje wjeloogniskowe grzybami z rodzaju Candida u chorych na raka piuca i przenteśą obturacyjną chorobạ pluc. Mikol. Lek. 6 (4): 207-211.

Dynowska M. 1993. Changes in mycoflora of men's respiratory systern - observed during last some years -yeasts. Acta Mycol. 28 (2): 151-155,

Dynowska M. 1995. Drozdze i grzyby drożdzonodobne jako cyynniki patcogenne oraz bioindykatory ekasystemów wodnyeh. Studie i Materialy WSP, Otsztyn 77:1-83.

Krajewska-Kutak E, tukaszuk C, Niczyporuk W, Krawcztik-Rybak M, Wojtukiewicz M., Ku lak W.. Sobaniec H. 1999. Częstớć izolacji graybúw drożdéopodobnych z matcriału pobrancgo $z$ ontocenozy jamy ustnej od pacjentów onkologicznych. Mikol. Lek. $6(4): 243-246$.

Kreger-van Rij N. J.W. 1984 . The yeasis A tasonomic study. Third revision and enlatgod edition. Els. Sci. Pabl. Amsterdam.

Kurnatowska A. 1995. Wybrane zagadnienia z mikologii medyeznej, Promedi. Lodz. 
Richardson M. D. Warnock D. W. 1995, Grzybice, Rozpoznawanie i leczenie. Sprigger PWN, Warszawa.

Senet J. M., Robert R. 1995. Physiopatholczic des candidoses, J. Mycol. Med. 5, 145-166.

Verthalitis I. Meunier F. 1995. Invasive fungal infections in cancer poilients. Prophylaxis of fugal infections. Bailliére's Clinical Infections Diseases, 2: 157.177.

Warnock D. W, Richardson M. D. (ed.) 1991. Fungal infection in the compromised patients, Chichester - John Wiley.

Zagórecka A. 1971. Mykologiczno serologiczna diagnostyka zakazen drożzakami Candida u chorych na gruźliç pluc. Ann. Acad. Med. kodż. Supl. 7, Lưdż: 37.

\section{Udział grzybów drożdzopodobnych w schorzeniach układu oddechowego - gruźlica i nowotwory}

\section{Streszezenie}

Praca obejmuje uyniki hadan (1997-1999) dotycrących wystepnowania grzybtox drożdzopodobnyhe w układzie oddechowym (phwocina, materinł bronchoskopomy) 1315 pacjentów Samodzielncgo Publicznego Zespołu Pulmunologii i Onkologii w Olszynie, u których rorwijat się proces nowotworcowy i podejrzanych o gruálicç.

W analizowanej grupie osób większosce pacjentów nowotworowych (452 osoty: 311 kobiet i 141 mężczyzn) byla zakazona grzybami. Wyizolowano je od 280 kobiet - 9050 i 130 męzcryzn $-92 \%$. Spostód 78 osób podejrzanych o gruźliç̣ i leczonych w tym kicrunku scriami antybiotyków, tylko w dwóch przypadkach wyhodowano prątki. U 76 osób prątkơw nie stwierdzono, mimo, ze objawy kliniczne oraz badania radiologiczne wykazywały zmiany gruálicre. Ogólem wyizolowzno 9 gatunków grzybów z rodzaju: Candida, Saccharamycopsis $i$ Trichosporon. Dominowala Candida albicons. Uzyskane wyniki potwierdzaja negatywry wptyw nowoczesnej terapii antybiotykowcj i przeciwnowotworowej, kı́ı́j nasıępstwem jest drastyezny spadek odporności onganizmu i uaktywnienie się grzybów potencjalnie chorobotworcrych często imitują̧cych objany innych chorób (m.in. gnuşlicy). 